ENVIRONMENTAL RESTORATION PROGRAM

\section{Completion Report for the Inactive Liquid Low-Level Waste Tank Remediation Project at Oak Ridge National Laboratory, Oak Ridge, Tennessee}

This document has been approved for release to the public by the ORNL Technical Information Officer. Date: 2/5/1996

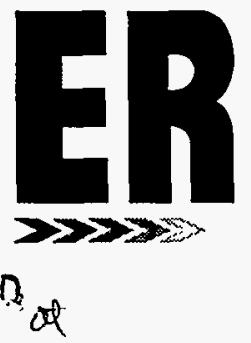




\section{H\&R Technical Associates, Inc.}

contributed to the preparation of this document and should not be considered an eligible contractor for its review.

This report has been reproduced directly from the best available copy.

Available to DOE and DOE contractors from the Office of Scientific and Technical Information, P.O. Box 62, Oak Ridge, TN 37831; prices available from 423-576-8401 (fax 423-576-2865).

Available to the public from the National Technical Information Service, U.S. Department of Commerce, 5285 Port Royal Rd., Springfield, VA 22161. 


\section{PREFACE}

This completion report for the Inactive Liquid Low-Level Waste Tank Remediation Project at Oak Ridge National Laboratory (ORNL), Oak Ridge, Tennessee, documents the accomplishment of the maintenance action to isolate and remove tanks 3001-B, 3004-B, and T-30 and to isolate and fill tank 3013 with grout. This work was performed under Work Breakdown Structure 6.1.01.21.20.50 (ADS 3301). The work performed is compared with that proposed in the statement of work and service contract specification.

\section{DISCLAIMER}

This report was prepared as an account of work sponsored by an agency of the United States Government. Neither the United States Government nor any agency thereof, nor any of their employees, makes any warranty, express or implied, or assumes any legal liability or responsibility for the accuracy, completeness, or usefulness of any information, apparatus, product, or process disclosed, or represents that its use would not infringe privately owned rights. Reference herein to any specific commercial product, process, or service by trade name, trademark, manufacturer, or otherwise does not necessarily constitute or imply its endorsement, recommendation, or favoring by the United States Government or any agency thereof. The views and opinions of authors expressed herein do not necessarily state or reflect those of the United States Government or any agency thereof. 



\section{CONTENTS}

ABBREVIATIONS $\ldots \ldots \ldots \ldots \ldots \ldots \ldots \ldots \ldots \ldots \ldots \ldots \ldots \ldots$ vii

EXECUTIVE SUMMARY $\ldots \ldots \ldots \ldots \ldots \ldots \ldots \ldots \ldots \ldots \ldots \ldots \ldots$ ix

1. INTRODUCTION AND SITE DESCRIPTION $\ldots \ldots \ldots \ldots \ldots \ldots \ldots \ldots \ldots \ldots$

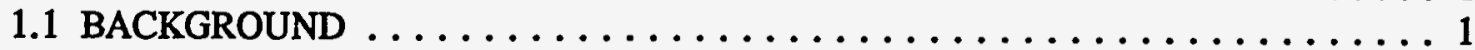

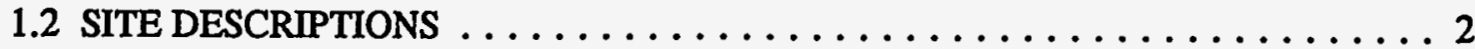

2. MAINTENANCE ACTION OBJECTIVES $\ldots \ldots \ldots \ldots \ldots \ldots \ldots \ldots \ldots \ldots$

3. INITIAL ASSUMPTIONS $\ldots \ldots \ldots \ldots \ldots \ldots \ldots \ldots \ldots \ldots \ldots \ldots \ldots$

4. MAINTENANCE ACTION WORK PLAN

METHOD OF ACCOMPLISHMENT $\ldots \ldots \ldots \ldots \ldots \ldots \ldots \ldots \ldots \ldots$

5. MAINTENANCE ACTION FIELD ACTIVITIES $\ldots \ldots \ldots \ldots \ldots \ldots \ldots \ldots \ldots$

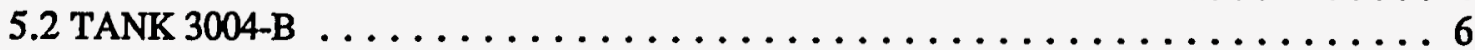

5.3 TANK T-30 $\ldots \ldots \ldots \ldots \ldots \ldots \ldots \ldots \ldots \ldots \ldots \ldots \ldots \ldots \ldots \ldots \ldots \ldots \ldots \ldots$

5.4 TANK $3001-B \ldots \ldots \ldots \ldots \ldots \ldots \ldots \ldots \ldots \ldots \ldots \ldots$

6. REMOVAL FROM FEDERAL FACILITY AGREEMENT LIST $\ldots \ldots \ldots \ldots \ldots$.

7. RETENTION OF MAINTENANCE ACTION RECORDS $\ldots \ldots \ldots \ldots \ldots \ldots$

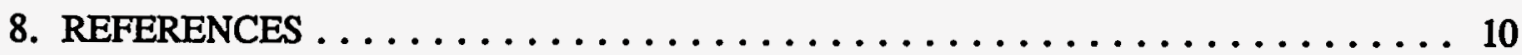





\section{ABBREVIATIONS}

AST Advanced Systems Technology, Inc.

CERCLA Comprehensive Environmental Response, Compensation, and Liability Act

DOE

EPA Department of Energy

FFA

HP

Environmental Protection Agency

IH Federal Facility Agreement

LLLW liquid low-level waste

ORNL Oak Ridge National Laboratory

ROD

SEG record of decision

TDEC Tennessee Department of Environment and Conservation 


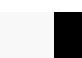




\section{EXECUTIVE SUMMARY}

This report documents the results of the Inactive Liquid Low-Level Waste Tank Remediation Project at Oak Ridge National Laboratory (ORNL). The work performed is compared with that proposed in the statement of work and the service contract specification for the maintenance action to remediate tanks 3013, 3004-B, T-30, and 3001-B.

The Federal Facility Agreement (FFA) among the U.S. Environmental Protection Agency (EPA), the Tennessee Department of Environment and Conservation (TDEC), and the U.S. Department of Energy (DOE) requires that all tanks, which have been removed from service and are designated in the FFA as Category D, must be remediated in accordance with the Comprehensive Environmental Response, Compensation, and Liability Act (CERCLA) requirements.

The Environmental Restoration Program's inactive tank removal program strategy and plans for remediating the inactive LLLW tanks were documented in a report issued in January 1995 (Inactive Tanks Remediation Program Strategy and Plans for Oak Ridge National Laboratory, Oak Ridge, Tennessee, ORNL/ER-297). The inactive (Category D) tanks were initially screened for remediation according to risk, remediation technology required, level of instrumentation available, interferences with other piping and equipment, location, and available sludge removal techniques and storage requirements. On the basis of this preliminary screening, the tanks were assigned to one of five batches (I through V) for consideration of remedial action alternatives, and these batches were tentatively scheduled for remedial actions. The eight tanks tentatively assigned to Batch I were divided into two groups (Series I and Series II).

A team was assembled to address remediation of the tanks in Batch I, Series I (3001-B, 3004-B, 3013, and $\mathrm{T}-30$ ). On the team were technical representatives from the involved organizations, including the ORNL Waste Management and Remedial Action Division, Energy Systems Environmental Restoration Division, Central Engineering Services, Risk Analysis, Chemical Technology Division, and subcontractors.

For the tanks in Batch I, Series I, the team planned to prepare documentation that would incorporate all the requirements of the CERCLA remedial action process (as required by the FFA) leading to a record of decision (ROD). The specific remediation alternative would be chosen on the basis of risk as described in EPA guidance manuals. A streamlined approach would combine the CERCLA Site Investigation, Remedial Investigation, Feasibility Study, and Proposed Plan requirements into a single Interim Proposed Plan document. Alternatives considered for each tank included removing and disposing of the tank, leaving the tank in place and isolating it from its associated piping, leaving the tank in place and filling it with a stabilizing agent, and taking no action. Following the selection of a preferred remedial action alternative and its documentation in the ROD, remedial design and remedial action were to proceed.

At the Regulatory Working Group meeting held on February 7, 1995, the team presented the remediation strategy and associated issues pertaining to the tanks in Batch I, Series I. The team also presented to the regulators the results of preliminary conceptual site modeling and preliminary risk assessments, which were completed on the basis of the initial assumptions and by using available characterization data. The consensus among EPA, TDEC, and DOE at this meeting was that because the risk associated with these tanks was low and the required remedial design would be minimal, the 
remediation of the tanks could proceed as a maintenance action. Remediating the tanks as a maintenance action would not require even the streamlined CERCLA documentation that the team had anticipated, thus resulting in a cost savings. Field experience in removing or fixing the tanks in place would still be gained with a maintenance-action approach.

The technical objectives of the maintenance action were to isolate the inactive tanks from their associated piping systems; remove tanks 3004-B, T-30, and 3001-B from their present locations and dispose of them as solid low-level radioactive waste; and secure tank 3013 in place by filling it with grout. When isolation of the piping and removal of the tanks from their respective vaults had been completed, the vaults were to be filled with grout.

The maintenance action for the four tanks was performed by a subcontractor, Advanced Systems Technology, Inc. (AST), in accordance with a statement of work and a service contract specification prepared by Lockheed Martin Energy Systems, Inc. Energy Systems Construction Engineering, Industrial Hygiene, and Health Physics personnel oversaw all field activities.

All of the technical objectives of the maintenance action were accomplished exactly as planned for tanks 3013, 3004-B, and 3001-B. The primary objective, that of isolating the tank from its associated system piping, was accomplished as planned for tank T-30. Because of higher than expected levels of contamination in tank T-30 and its associated vault, the removal of the tank from the vault and the filling of the vault with grout has been postponed pending further decontamination. The specific objectives and the degree to which the objectives were met are summarized in the table on the next page.

Completion of this maintenance action is noteworthy in that it represents the transition from the planning phase to the actual conduct of field activities resulting in removal and disposal of inactive tanks in the ER program.

Background on the decision-making process leading to the maintenance action is provided in Sect. 1 and the four tank sites as they existed at the beginning of the maintenance action are described. In Sects. 2 and 3, the maintenance action objectives and initial assumptions concerning the tank sites are discussed. In Sect. 4, the method of accomplishment for the project is described, and accomplishments are compared with the project requirements. Formal removal of the tanks from the FFA Appendix $F$ list of inactive tanks is addressed in Sect. 6, and other records documenting the completion of the maintenance action are addressed in Sect. 7. 
Accomplishment of technical objectives in remediating inactive liquid low-level waste tanks

Technical

objectives
Objective accomplished

TANK 3013

Isolate associated system piping

Fill tank with grout

Dispose of removed piping and

equipment

Isolate associated system piping

Remove tank

Dispose of tank and removed piping

and equipment

Fill tank vault and valve pit with grout

Isolate associated system piping

Remove tank

Dispose of tank and removed piping and equipment

Fill tank vault with grout

Isolate associated system piping

Remove tank

Dispose of tank and removed piping

and equipment

Install bypass piping for 3001 canal

demineralizer to tank WC-19

Fill tank vault with grout
Yes

Yes

Yes

TANK 3004-B

Yes

Yes

Yes

Yes

TANK T-30

Yes

No

No

No

\section{TANK 3001-B}

Yes

Yes

Yes

Yes

Yes

\section{Comments}

All maintenance action objectives were met for tank 3013.

All maintenance action objectives were met for tank 3004-B.

The primary maintenance action objective was met for tank T-30. Removal of the tank and filling the vault with grout have been postponed pending further decontamination of the tank and vault.

All maintenance action objectives were met for tank 3001-B. 



\section{INTRODUCTION AND SITE DESCRIPTION}

\subsection{BACKGROUND}

The Federal Facility Agreement (FFA) among the U.S. Environmental Protection Agency (EPA), the Tennessee Department of Environment and Conservation (TDEC), and the U.S. Department of Energy (DOE) requires that all liquid low-level waste (LLLW) tanks at Oak Ridge National Laboratory (ORNL) that have been removed from service, designated in the FFA as Category D, must be remediated in accordance with Comprehensive Environmental Response, Compensation, and Liability Act (CERCLA) requirements.

The Environmental Restoration (ER) Program's inactive tank removal program strategy and plans for remediating the inactive LLLW tanks were documented in a report, which was issued in June 1995.(ORNL 1995b) The inactive (Category D) tanks were initially screened for remediation according to risk, remediation technology required, level instrumentation available, interferences with other piping and equipment, location, and available sludge removal techniques and storage requirements. On the basis of this preliminary screening, the tanks were assigned to one of five "batches" (I through V) for consideration of remedial action alternatives, and these batches were tentatively scheduled for remedial actions. The eight tanks tentatively assigned to Batch I were divided into two groups (Series I and Series II).

The approach to remediation of each tank or batch of tanks was viewed as a dynamic, flexible process that must be adapted in response to the specific circumstances of individual tank systems. The approach was tailored to accommodate feedback on lessons learned from previous remediation actions and was not a rigid step-by-step approach to be conducted identically for every tank system.

A team was assembled to address remediation of the tanks in Batch I, Series I (3001-B, 3004-B, 3013, and T-30). The team consisted of technical representatives from the involved organizations, including ORNL Waste Management and Remedial Action Division, Energy Systems Environmental Restoration Division, Central Engineering Services, Risk Analysis, Chemical Technology Division, and appropriate subcontractors.

For the tanks in Batch I, Series I, the team planned to prepare documentation that would incorporate all the requirements of the CERCLA remedial action process (as required by the FFA) leading to a record of decision (ROD). The specific remediation alternative would be chosen on the basis of risk as described in EPA guidance manuals. A streamlined approach would combine the CERCLA Site Investigation, Remedial Investigation, Feasibility Study, and Proposed Plan requirements into a single Interim Proposed Plan document. Alternatives considered for each tank included removing and disposing of the tank, leaving the tank in place and isolating it from its associated piping, leaving the tank in place and filling it with a stabilizing agent, and taking no action. Following the selection of a preferred remedial action alternative and its documentation in the ROD, remedial design and remedial action were to proceed.

At the Regulatory Working Group Meeting held on February 7, 1995, the team presented the remediation strategy and associated issues pertaining to the tanks in Batch I, Series I. The team also presented to the regulators the results of preliminary conceptual site modeling and preliminary risk assessments that were completed on the basis of the initial assumptions and by using available 
characterization data. Consensus among EPA, TDEC, and DOE at this meeting was that because the risk associated with these tanks was low and the required remedial design would be minimal, the remediation of the tanks could proceed as a maintenance action outside of the CERCLA process. Remediating the tanks as a maintenance action would not require even the streamlined CERCLA documentation that the team had anticipated, thus resulting in a cost savings. Field experience in removing or fixing the tanks in place would still be gained with a maintenance action approach.

\subsection{SITE DESCRIPTIONS}

This section describes the tank sites as they were when the maintenance action began.

\subsubsection{Tank 3013}

Tank 3013 is located east of Bldg. 3017 and south of Bldg. 3013. The 400-gal stainless steel tank is buried directly in the soil and has no vault enclosure. The tank was installed in 1949 and received waste from Bldg. 3013, an environmental processing laboratory that dealt with low-level contaminated environmental samples. Tank 3013 is a vertical, cylindrical tank measuring approximately $3 \mathrm{ft} 6$ in. OD by $5 \mathrm{ft} 6 \mathrm{in}$. tall and has several pipe risers to the surface of the soil. Available drawings show that the tank is bolted to a 5-ft-diam, 12-in.-thick concrete pad. The bottom of the tank is approximately $12 \mathrm{ft}$ below ground. Health physics (HP) surveys reported $0.01 \mathrm{mrad} / \mathrm{h}$ at the top of the largest pipe riser and $0.02 \mathrm{mrad} / \mathrm{h}$ inside the tank. The tank contains no liquid or sludge.

\subsubsection{Tank 3004-B}

Tank 3004-B is located east of Bldg. 3008, beneath landscape rocks adjacent to the public access walkway to the Graphite Reactor. The 100-gal stainless steel tank is enclosed in an in-ground, unlined concrete vault with a removable vault cap. The tank was installed in 1956 and was used as a waste holding tank for the Low Intensity Test Reactor. The tank was taken out of service in 1968. Tank $3004 \mathrm{~B}$ is a vertical, cylindrical tank measuring approximately $2 \mathrm{ft} 6 \mathrm{in}$. OD by $3 \mathrm{ft}$ tall. HP surveys reported no detectable contamination outside the tank except for $1400 \mathrm{dpm} / 100 \mathrm{~cm}^{2}$ at the edge of the vault. The tank contains no liquid or sludge.

\subsubsection{Tank T-30}

Tank T-30 is located south of Bldg. 4507, in an in-ground, unlined concrete vault. The 825-gal stainless steel tank was installed in 1961 and received radioactive waste from Bldg. 4507 hot cells. The tank was removed from service in 1980 . Tank T-30 is a vertical, cylindrical tank that measures approximately $4 \mathrm{ft} 6$ in. OD by $8 \mathrm{ft} 2$ in. tall. A cooling water jacket surrounds the lower half of the tank. The tank is shielded with approximately 1200 lead bricks and contains no liquid or sludge.

\subsubsection{Tank 3001-B}

Tank 3001-B is located south of Bldg. 3001 under the concrete stairway landing adjacent to the building's foundation. The 300-gal stainless steel tank is contained in an unlined concrete vault and cap with limited access through a 1\%/4-in.-diam riser. The tank was installed in 1943 and was used as a holding tank for radioactive laboratory waste from Bldg. 3001. It was taken out of service in 1965. Tank 3001-B is a vertical, cylindrical tank measuring approximately $4 \mathrm{ft}$ OD by $4 \mathrm{ft}$ tall. HP surveys reported $0.4 \mathrm{mrad} / \mathrm{h}$ at the top of the riser and $80 \mathrm{mrad} / \mathrm{h}$ at the bottom of the tank. The tank contains no liquid or sludge. 


\section{MAINTENANCE ACTION OBJECTIVES}

The technical objectives of the maintenance action were to isolate the inactive tanks from their associated piping systems; remove tanks 3004-B, T-30, and 3001-B from their present locations and dispose of them as solid low-level radioactive waste; and secure tank 3013 in place by filling it with grout. Upon isolation of the piping and removal of the tanks from their respective vaults, the vaults were to be filled with grout. The grout was specified as a controlled low-strength material consisting of a mixture of Type II cement, sand, fly ash, and water having a compression strength of approximately 300 psi and a permeability of approximately $2 \times 10^{-5} \mathrm{~cm} / \mathrm{s}$. Filling tank 3013 and the vaults and valve pits associated with the other tanks with grout will prevent the accumulation of any free liquids in the tank or the vaults. The low compressive strength of the grout will pose minimum hinderance to future soils remediation at the sites. The low permeability will effectively prevent the accumulation of free liquids in the tank or the vaults.

Achieving the stated maintenance action objectives will eliminate any further surveillance and maintenance expenses for the tanks. A secondary objective of the maintenance action was to obtain knowledge and experience that could be applied to future tank removal actions. The maintenance action described in this report included the following specific activities:

- cut and cap the piping connected to tank 3013 and fill the tank with grout;

- cut and cap the piping connected to tank 3004-B, remove the tank from its vault, and fill the tank vault and adjacent valve pit with grout;

- cut and cap the piping connected to tank T-30, remove the tank from its vault, and fill the vault with grout;

- remove tank 3001-B from its vault, restore the waste discharge line from the 3001 canal demineralizer to tank WC-19, and fill the vault with grout; and

- transport the removed tanks, piping, and equipment to Scientific Ecology Group, Inc., (SEG) for smelting or store the tanks, piping, and equipment at the appropriate ORNL waste storage facility.

\section{INITIAL ASSUMPTIONS}

Several initial assumptions were made about the status and configuration of the tank systems before the beginning of the maintenance action. Discussion of assumptions that could have a significant impact on the completion of the maintenance action along with technical justifications for these assumptions are presented here.

The tanks in this maintenance action were assumed to be empty and to contain no significant amount of liquid or sludge resulting from their use for waste collection. All the tanks were accessible for verification of this assumption and were inspected and found to be free of significant amounts of liquid. Inspection revealed that none of the tanks contained sludge. Tanks 3004-B, 3001-B, and T-30 
contained residual liquid below a level that could be removed by ordinary pumping means. An absorbent material was added to the tanks to eliminate this small amount of free liquid.

Early in the planning phase for the maintenance action, available characterization data, derived from analysis of samples from the last liquid removed from the tanks, was assumed to be adequate to characterize the tanks for disposal. On the basis of this characterization, all the tanks were assumed able to meet the appropriate waste acceptance criteria for smelting at SEG or storage at ORNL waste storage facilities. The waste management plan for the maintenance action required that representative smears from the inside of at least one of the tanks be assessed to verify the validity of the previous characterization.

Available engineering drawings were assumed to have accurately reflected tank and piping configuration. For tanks 3004-B and T-30, this assumption could be verified visually after removing the tank vault covers. The configuration of tanks 3013 and 3001-B could not be verified until the piping had been excavated in the case of tank 3013 or until the vault had been excavated and the vault covers removed for tank 3001-B. The engineering drawings listed in Sect. 7 will be revised to show the "as-built" configuration of the piping systems remaining at the sites after completion of the maintenance action.

\section{MAINTENANCE ACTION WORK PLAN METHOD OF ACCOMPLISHMENT}

The purpose of the maintenance action was to isolate the tanks from their associated piping systems and then either remove the tanks or fill them with grout, thus eliminating any continuing or future liability for surveillance and maintenance of the tanks. The maintenance action fieldwork was done by Advanced Systems Technology, Inc. (AST), an off-site service contractor. The fieldwork was done in accordance with a service contract specification prepared by Energy Systems (ORNL 1995a). Energy Systems, as integrating contractor for DOE, performed the sampling and analysis, off-site waste transport, and waste management and oversaw the field maintenance activities.

\section{MAINTENANCE ACTION FIELD ACTIVITIES}

In this section, a list of requirements for field activities at each tank is followed by a discussion of the activities carried out to meet the requirements. The requirements listed were taken from the service contract specification (ORNL 1995a).

An overall chronology of events for the remedial action field activities is presented in Table 1. 
Table 1. Chronology of events

\begin{tabular}{|c|c|}
\hline Date & Event \\
\hline 31JUL95 & Mobilized at 3013 site. \\
\hline 01AUG95 & Began excavation to expose tank 3013 piping. \\
\hline 02AUG95 & Filled tank 3013 with grout. \\
\hline 03AUG95 & Began cutting to isolate tank 3013 system piping. \\
\hline 04AUG95 & Completed cutting pipes, welding caps, and inspecting welds for pipe isolation. \\
\hline 08AUG95 & $\begin{array}{l}\text { Cleaned up } 3013 \text { site; completed grading and grass reseeding. } \\
\text { Mobilized at 3004-B site. }\end{array}$ \\
\hline 09AUG95 & $\begin{array}{l}\text { Began tank 3004-B task by removing tank vault cover. Cut and welded caps on all } \\
\text { lines. Removed tank 3004-B from vault. }\end{array}$ \\
\hline 10AUG95 & $\begin{array}{l}\text { Placed grout in tank 3004-B vault and valve pit. Replaced vault cover and cleaned } \\
\text { up site. Placed tank 3004-B in B-25 box for transport to waste disposal. }\end{array}$ \\
\hline 12AUG95 & Mobilized at tank T-30 site. \\
\hline 16AUG95 & Cut all pipe lines to tank $T-30$. \\
\hline 24AUG95 & Completed capping all lines to tank T-30. \\
\hline 01 SEP95 & $\begin{array}{l}\text { Began applying strippable coating to immobilize loose contamination in T-30 tank } \\
\text { vault. }\end{array}$ \\
\hline 12SEP95 & Decision made that tank T-30 cannot be shipped and will remain in vault. \\
\hline 15SEP95 & $\begin{array}{l}\text { Mobilized at 3001-B site. Began relocating stairs and breaking concrete above tank } \\
\text { vault. }\end{array}$ \\
\hline 26SEP95 & Completed removal of tank 3001-B vault covers. \\
\hline 28SEP95 & Cut and capped two $1 / 2$-in. lines connected to tank 3001-B. \\
\hline $020 C T 95$ & Removed tank 3001-B from vault and delivered tank to Waste Management. \\
\hline $100 \mathrm{CT} 95$ & Completed installation of piping from 3001 canal demineralizer to tank WC-19. \\
\hline $130 \mathrm{CT} 95$ & Replaced stairs in original location and completed form work for concrete landing. \\
\hline $160 \mathrm{CT} 95$ & Completed concrete placement over tank 3001-B vault. \\
\hline $180 \mathrm{CT95}$ & Demobilized at 3001-B site; completed cleanup of area. \\
\hline
\end{tabular}




\subsection{TANK 3013}

\subsubsection{Requirements}

- Mobilize and set up work area boundary, silt fencing, hay.

- Excavate to a depth of 3 to $4 \mathrm{ft}$ at tank location.

- Set up temporary containment tent, if required.

- Cut and cap all exposed lines 3 to $4 \mathrm{ft}$ below grade.

- Fill tank with grout.

- Backfill with removed soil (top $1 \mathrm{ft}$ may require clean fill).

- Demobilize, clean up area, seed and mulch.

\subsubsection{Activities}

AST mobilized at the tank 3013 site and established the work area boundaries, surface water control measures, and support facilities before beginning the excavation. Surveys by Industrial Hygiene (IH) and HP indicated that a containment tent was not required. The soil directly above the tank was excavated to a depth of approximately 3 to $4 \mathrm{ft}$. Because of the congested area around the site and uncertainty about the exact location of piping in the area, all excavation was done by hand (using shovels). Excavated soil was surveyed for radioactive contamination and stockpiled at the site for use as backfill after the pipes were capped and the tank was filled with grout. The tank was completely filled with grout. Exposed lines were cut and capped 3 to $4 \mathrm{ft}$ below grade. All excavated soil was determined to be Category 1 and was replaced. The area was graded and reseeded, and the site was left as an unrestricted access area. No deviation from the work described in the service contract specification was required for the tank 3013 maintenance action. All objectives of the maintenance action for tank 3013 were met.

\subsection{TANK 3004-B}

\subsubsection{Requirements}

- Mobilize and set up work area boundary, silt fencing, hay, etc.

- Remove decorative rocks.

- Remove vault cover.

- Set up temporary containment tent, if required.

- Cut and cap lines. Cut lines at vault boundary.

- Remove tank, determine actual weight, and transport and place inside sea/land container.

- Fill tank vault and valve pit area with grout.

- Replace vault cover.

- Clean up and replace rocks. 


\subsubsection{Activities}

AST mobilized at the 3004-B site and established the work area boundaries and support facilities before removing the tank vault cover. Because no excavation was required, surface water control measures were not required. Surveys by IH and HP indicated that no containment tent was required. The vault cover was removed, and all lines connected to tank 3004-B were cut and capped. The tank was removed from the concrete vaul,t and the vault and adjacent valve pit were filled with grout. Tank 3004-B was placed in a B-25 box for disposal by Waste Management. The vault cover was placed back in position atop the grout-filled vault and the landscape features restored to their former condition. No deviation from the work described in the service contract specification was required for the tank 3004-B maintenance action. All objectives of the maintenance action for tank 3004-B were met.

\subsection{TANK T-30}

\subsubsection{Requirements}

- Mobilize and set up work area boundary, silt fencing, hay.

- Remove steel plates and shielding.

- Set up temporary containment tent, if required.

- Cut and cap lines. Cut lines at vault boundary.

- Remove tank, determine actual weight, and transport to and place inside sea/land container.

- Fill vault with grout.

- Pour 6-in.-thick reinforced concrete pad over pit.

- Clean up.

\subsubsection{Activities}

AST mobilized at the tank T-30 site. Because of previous work in the vault by MK-Ferguson, a work area boundary and containment tent had already been put in place. Before AST began isolation of tank T-30, MK-Ferguson had removed about 800 of the approximately 1200 lead shielding bricks that were in the tank vault. AST began cutting and welding caps on all lines connected to tank T-30. Unexpectedly high concentrations of airborne contamination were encountered during the welding process. Investigation revealed that curium that had plated on the interior surfaces of tank T-30 and associated piping had vaporized as a result of the welding heat and was the source of the increased airborne contamination. After taking appropriate measures for contamination control and personnel protection, the cutting and welding of all piping connected to tank $\mathrm{T}-30$ was completed, and lugs were welded onto the tank in preparation for lifting the tank from the vault.

Because of the unexpected surface contamination on the inside of tank T-30, the tank could not be transported to SEG for smelting, and the decision was made to leave the tank in the vault pending further decontamination of the tank and vault. The tank was temporarily relocated within the vault to allow removal of the lead shielding bricks that were located between the tank and the vault wall, and 
then the tank was replaced in its original position. Strippable coating was applied to the tank exterior and to the vault walls to immobilize the loose contamination. Application of the strippable coating was a deviation from the work originally prescribed in the maintenance action contract specification. Although tank T-30 was not removed from the tank vault and the vault was not filled with grout, the primary objective of isolating the tank from its system piping was accomplished. Root causes for the deviation from the originally specified work and final disposition of tank T-30 and the tank vault will be addressed in a separate report.

\subsection{TANK 3001-B}

\subsubsection{Requirements}

- Mobilize and set up work area boundary, silt fencing, hay.

- Relocate stairs above landing.

- Remove asphalt and concrete pad; send to landfill.

- Excavate to top of tank vault.

- Lift three vault covers.

- Set up temporary containment tent, if required.

- Cut inlet and discharge lines.

- Remove tank, determine actual weight, and transport to and place inside sea/land container.

- Add single-walled, stainless steel, schedule $\mathbf{4 0}$ pipe section to connect inlet to discharge.

- Plug french drain opening at southwest corner of vault.

- Fill tank vault with grout.

- Backfill and rework concrete landing. Replace removed asphalt with concrete.

- Replace stairs.

- Clean up.

\subsubsection{Activities}

AST mobilized at the tank 3001-B site and established the work area boundaries, surface water control measures, and support facilities. The stairs, which terminated at a concrete landing atop the 3001-B vault, were relocated to allow access for excavating to expose the concrete vault covers. The concrete pad was demolished and, along with the asphalt removed from above the tank vault, taken to the landfill. The three vault covers were lifted to gain access to tank 3001-B and its associated piping. Inspection of the tank and associated piping revealed two $1 / 2$-in. lines that were not clearly depicted on the available engineering drawings. Although initial IH and HP surveys indicated that no containment tent was required at the site, a containment tent was erected owing to the unknown condition inside the two $1 / 2$-in. lines. The two $1 / 2$-in. pipes connecting to the tank were disconnected at existing unions and capped. The 3-in. inlet and discharge pipes were cut from the tank and the tank was removed from the vault and transferred to Waste Management for disposal. A spool piece was fabricated and installed to reconnect the tank inlet and discharge lines, thus restoring the flow path 
from the 3001 canal demineralizer regeneration discharge piping to tank WC-19. Upon completion of weld inspections and leak testing of the new piping installation, the vault was filled with grout and the vault covers replaced in their original positions. The asphalt that was removed was replaced with concrete and a new concrete stair landing was formed and poured. The stairs were returned to their original configuration and the site was cleaned up. Cutting and capping of the two $1 / 2-i n$. lines that were not clearly shown on available design drawings were the only deviations from the work described in the service contract specification for the tank 3001-B maintenance action. All objectives of the maintenance action for tank 3001-B were met.

\section{REMOVAL FROM FEDERAL FACILITY AGREEMENT LIST}

Completion of this maintenance action has met the intent of the FFA for remediation of inactive tanks 3013, 3004-B, and 3001-B. DOE, EPA, and TDEC will be requested to approve a change to the FFA document removing these tanks from the Appendix $F$ list of inactive tanks. A change requesting removal of tank $\mathrm{T}-30$ from the Appendix $\mathrm{F}$ list will be submitted pending final disposition of the tank.

\section{RETENTION OF MAINTENANCE ACTION RECORDS}

Records for the maintenance action will be retained as prescribed in the project records plan (Ross November 1994).

The engineering drawings identified in Table 2 were revised and will be maintained in the Engineering Design Information System to show the as-built status of the piping systems remaining at the tank sites.

Table 2. As-built drawings

\begin{tabular}{ll}
\hline Tank no. & Drawing \\
\hline 3013 & D-1254, D-1051 \\
$3004-B$ & D-14271, D-14272, D-23742 \\
T-30 & P12020-CB-196-D, P12020-CB-198-D \\
$3001-B$ & W-68871, W-69106 \\
\hline
\end{tabular}




\section{REFERENCES}

Oak Ridge National Laboratory. 1995a. Service Contract Specification for Inactive Tanks 3001-B, 3004-B, 3013, and T-30, Martin Marietta Energy Systems, Oak Ridge, Tennessee, April.

Oak Ridge National Laboratory. 1995b. Inactive Tanks Remediation Program Strategy and Plans for Oak Ridge National Laboratory, Oak Ridge Tennessee, ORNL/ER-297, Lockheed Martin Energy Systems, Inc., Oak Ridge, Tennessee, June.

Ross, R.G., Jr. 1995. Inactive Tanks Remediation Program Project Records Plan, Oak Ridge National Laboratory, November. 


\section{DISTRIBUTION}

1. P. W. Allen

2. L. V. Asplund

3. J. Baxter

4. C. A. Bednarz

5. H. L. Boston

6. W. D. Brickeen

7. C. Clark

8. M. Clauberg

9. K. L. Deroos

10. C. H. Dukes

11. J. T. Etheridge

12-13. D. L. Garrett

14. H. K. Hepworth

15. L. L. Kaiser

16. A. J. Kuhaida, Jr.

17. G. R. Larson

18. D. M. Matteo

19-20. P. T. Owen

21. R. G. Ross, Jr.

22. A. W. Saulsury

23. P. A. Schrandt

24. C. B. Scott

25. A. Smith

26-27. D. K. Stair

28. W. T. Thompson

29. M. L. Whitehead

30. Central Research Library

31. Y-12 Technical Library

32. Laboratory Records Department

33-34. ER Document Management Center-RC

35-36. Office of Scientific and Technical Information, P. O. Box 62, Oak Ridge, TN 37831 


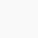

